\title{
Comparison of the specificity of interaction of cellular and viral zinc-binding domains with 2-mercaptobenzamide thioesters
}

Lisa M. Miller Jenkins, Stewart R. Durell, Andrew T. Maynard, Stephen J. Stahl, John K. Inman, Ettore Appella, Pascale Legault, and James G. Omichinski

Supplement to References:

17. Rice, W. G.; Supko, J. G.; Malspeis, L.; Buckheit, R. W., Jr.; Clanton, D.; Bu, M.; Graham, L.; Schaeffer, C. A.; Turpin, J. A.; Domagala, J.; Gogliotti, R.; Bader, J. P.; Halliday, S. M.; Coren, L.; Sowder II, R. C.; Arthur, L. O.; Henderson, L. E., Inhibitors of HIV nucleocapsid protein zinc fingers as candidates for the treatment of AIDS. Science 1995, 270, 1194-7.

51. MacKerell Jr., A. D.; Bashford, D.; Bellott, M.; Dunbrack Jr., R. L.; Evanseck, J. D.; Field, M. J.; Fischer, S.; Gao, J.; Guo, H.; Ha, S.; Joseph-McCarthy, D.; Kuchnir, L.; Kuczera, K.; Lau, F. T. K.; Mattos, C.; Muchnick, S.; Ngo, T.; Nguyen, D. T.; Prodhom, B.; Reiher III, W. E.; Roux, B.; Schlenkrich, M.; Smith, J. C.; Stote, R.; Straub, J.; Watanabe, M.; Wiorkiewicz-Kuczera, J.; Yin, D.; Karplus, M., All-atom empirical potential for molecular modeling and dynamics. Studies of proteins. J. Phys. Chem. B 1998, 102, 3586-3616. 
A

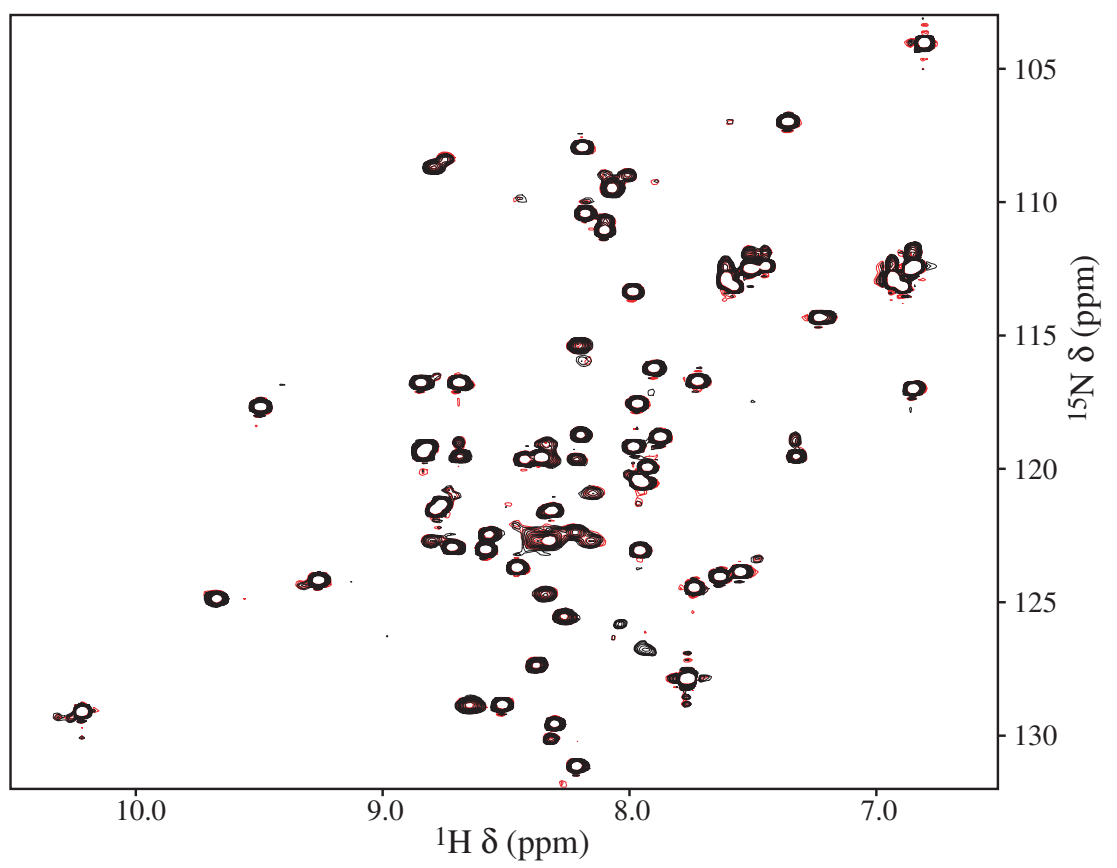

B

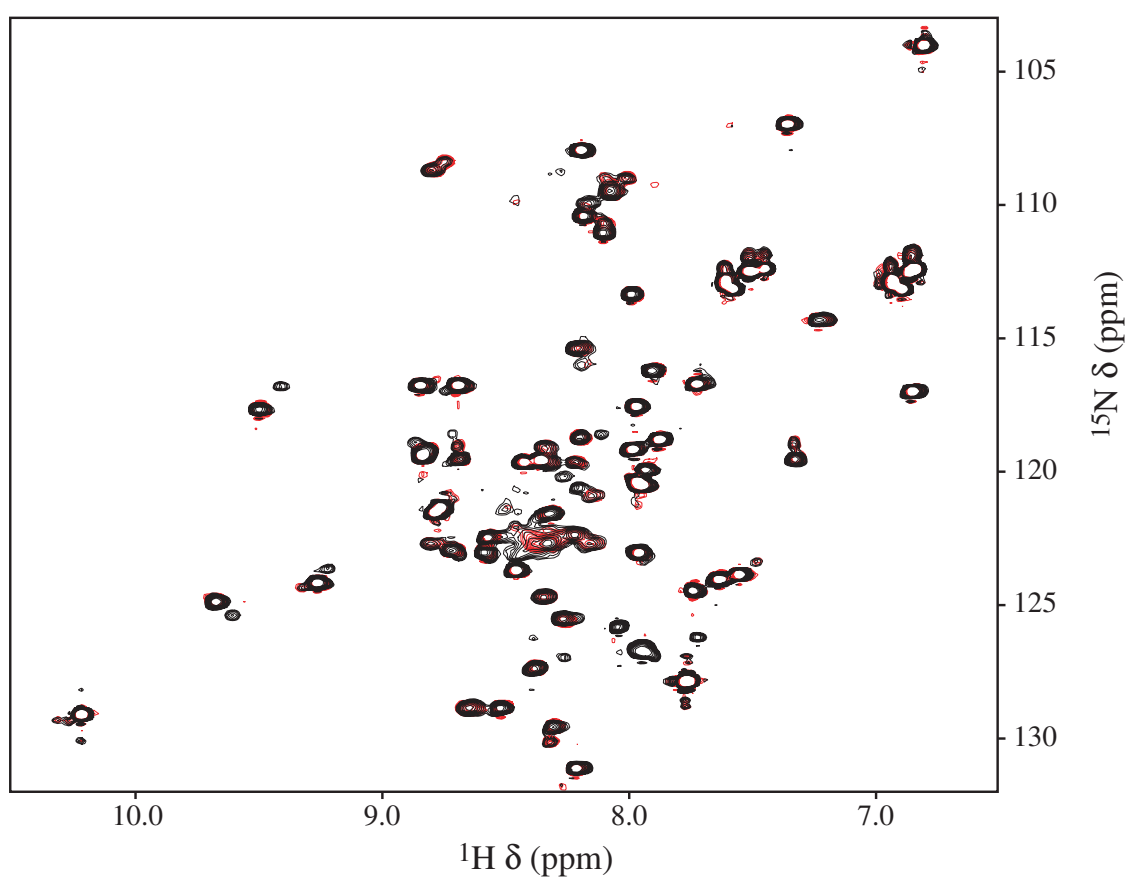

Supplementary Figure 1: Overlay of the $2 \mathrm{D}{ }^{1} \mathrm{H}_{-}{ }^{15} \mathrm{~N}$ HSQC spectra of ${ }^{15} \mathrm{~N}$-labeled MMTV NCp10 in the free form (red signals) and after incubation with compound $\mathbf{1}$ (black signals) for either $0 \mathrm{~h}(\mathrm{~A})$ or $48 \mathrm{~h}(\mathrm{~B})$. 

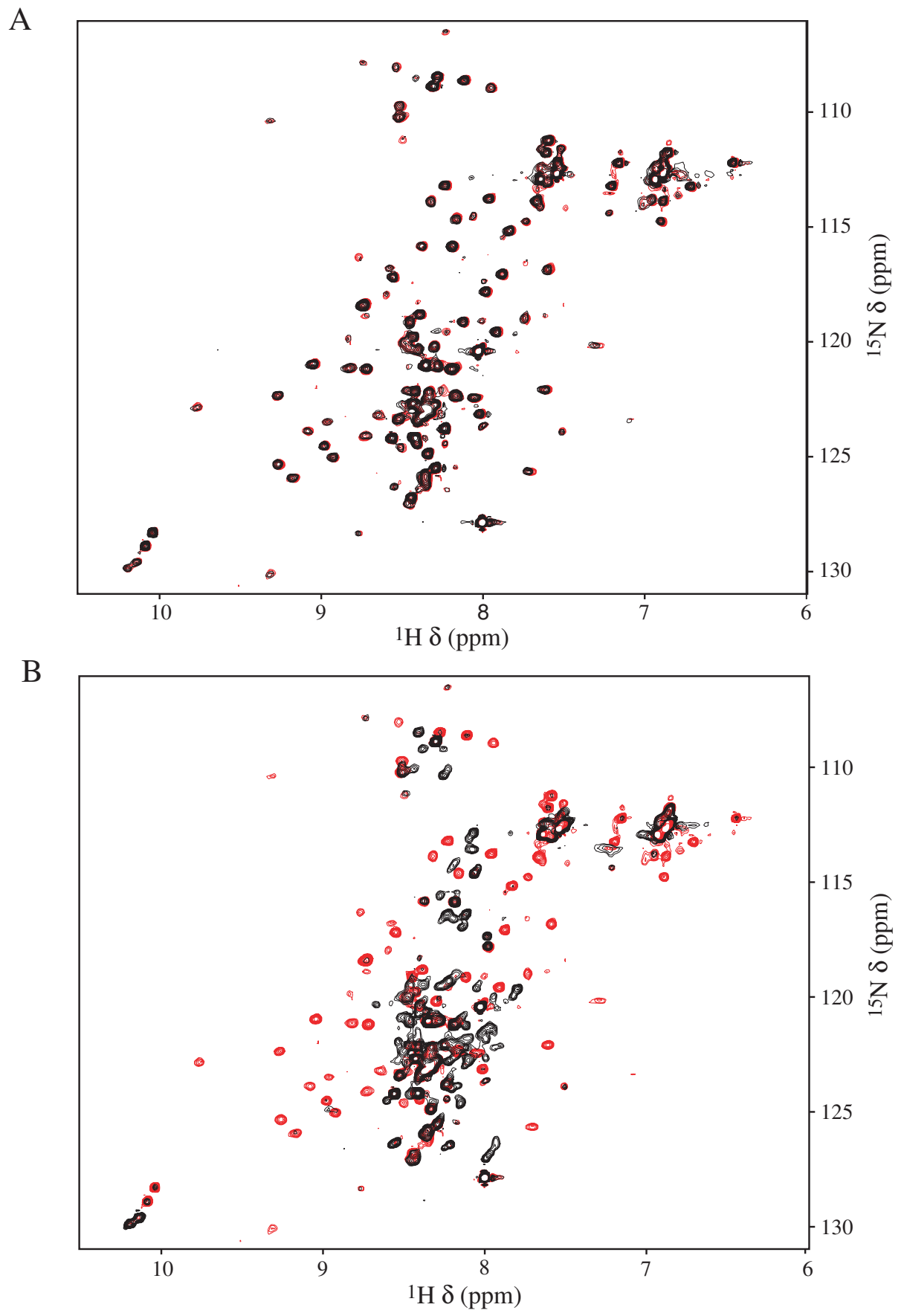

Supplementary Figure 2: Overlay of the 2D ${ }^{1} \mathrm{H}^{-15} \mathrm{~N}$ HSQC spectra of ${ }^{15} \mathrm{~N}$-labeled hGATA- $1_{200-317}$ in the free form (red signals) and after the incubation with compound $\mathbf{1}$ (black signals) for either a $0 \mathrm{~h}(\mathrm{~A})$ or $48 \mathrm{~h}(\mathrm{~B})$. 

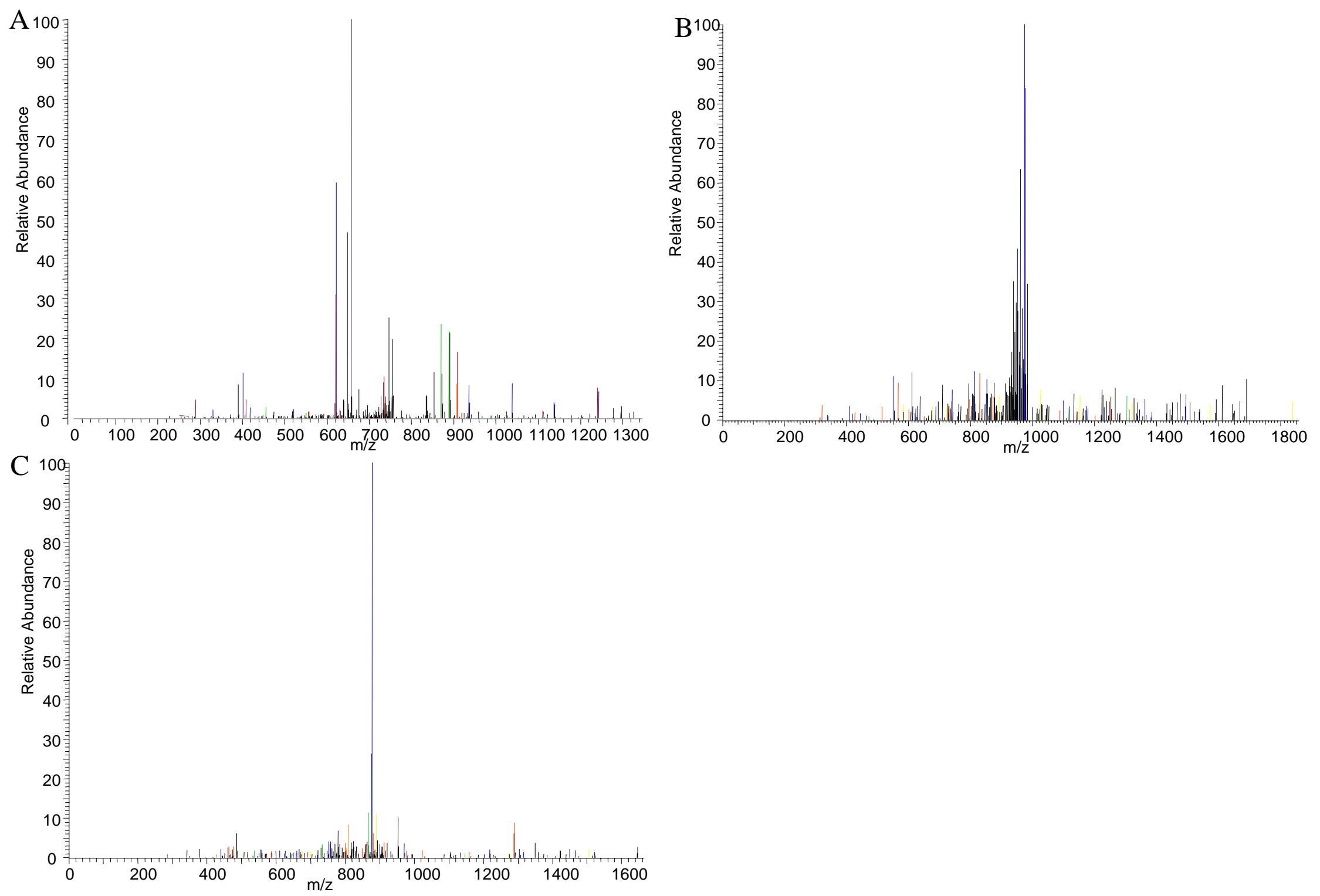

Supplementary Figure 3: MS/MS spectra of cGATA-1 $1_{158-223}$ peptides showing adduct formation on Cys ${ }_{164}$ and Cys $_{167}($ A $)$, on Cys $_{185}$ (B), and on $\mathrm{Cys}_{188}$ (C). A) Peptide sequence: VCSNCQTSTTTLW. B) Peptide sequence: GDPVCNACGLYYKLHQVNRPLTMR. C) Peptide sequence: DPVCNACGLYYKLHQVNRPLTMR. In each spectrum, peaks for y ions are blue, b ions are red, a ions are green, and c ions are yellow. 